\title{
Developing English Speaking Materials Based on The Contextual Teaching and Learning for Grade XI Senior High School in SMA \\ Negeri 1 Kerajaan
}

\author{
${ }^{1}$ Friski Padang \\ ${ }^{* *}$ Sumarsih \\ ${ }^{* *}$ Anggraini Thesisia Saragih
}

\begin{abstract}
Padang, Friski. Registration Number: 2133321016. Developing English Speaking Materials Based on The Contextual Teaching and Learning for Grade XI Senior High School in SMA Negeri 1 Kerajaan. A Thesis. English Educational Program. State University of Medan, 2018.

This study aim to design English speaking materials needed for students of class XI SMA N 1 Kerajaan. This study was conducted by using Research and Development ( $\mathrm{R} \& \mathrm{D})$ design through six stages; gathering information and data, analyzing data, designing materials, validating by experts, revising, and final product. The subject of this study were students of class XI consisting of 20 students. The instruments for collecting the data were questionnaire and interview. After analyzing the data, the writer got the students' needs. The data were gathered by administering interview to the English teacher and distributing the questionnaire to 20 respondents to get the students' needs. The interview and questionnaire result of the needs analysis showed that the students needed materials for speaking which were attractive and interesting and based on their social life context. Thus, the learning materials were developed into 6 of speaking material. By two experts; English lecturer and English teacher. The average scores are 4,7 or 95\% from English Lecturer and 4,5 or 90\% from English Teacher. It means the developing materials categorized as relevant, thus, it can be concluded that contextual teaching and learning speaking materials had been appropriated for grade XI students of Senior High School.
\end{abstract}

Key words: Research and Development ( $R \& D)$, Speaking materials, Contextual

Teaching and Learning

${ }^{1}$ Graduate Status

** Lecturer Status 


\title{
INTRODUCTION
}

\author{
Background of The Study
}

English, as one of the subjects at school has four language skills to learn, they are reading, writing, listening and speaking. Every skill has different levels of difficulties. To master this subject, students should get the same portion of every skill in the learning process. However, most of the teachers in Senior High School only focus on reading, writing and listening skills. They emphasized these three skills, because those are the only skills which are needed by the students to pass the national examination. This fact implies to the least portion for the students not getting speaking skill sessions when they learn English in the classroom.

Speaking becomes one of the four basic language skills that should be learned by the students in any level, because it is used by someone to deliver his/her opinion, thought, feeling, etc to other in order the messages can be clearly received by the listener. Nowadays, the world requires that the goal of teaching English should improve the students communicative skills, because in that way they can express themselves and learn how to follow the social and cultural rules appropriately in every communicative circumstances. Nunan (2003:48), states that speaking skill in a new language is more difficult than other skills'. Moreover, as Indonesians who are not English speaker, the students will not feel easy to speak in English, because they are not accustomed. Besides, speaking is also natural in which the students cannot 
easily revise what they have said, so tend to be afraid to speak in English. Therefore, it becomes a challenge for English teacher to teach the student to be able to use the language in real communication.

The least portion of speaking sessions in the classroom makes the students face some problems, such as the lack of vocabulary and the difficulty in expressing their feeling, since they do not know much about expression. For example, they are feel difficult to express and even to understand the transactional conversation and text in the book. The writer believes that students have problems in speaking skill because there is no specific book and appropriate materials used by their teacher to support their speaking skill improvement.

Based on the researcher's observation done toward the students at SMA NEGERI I KERAJAAN, it was found that their speaking didn't reach the competency because they simply lack of speaking materials because mostly the general English textbooks which they used only focus on the writing and reading comprehension, so that the students still get difficulties in expressing conversation. It was also difficult for them to express and even to understand the transactional conversation and text in the book.

In the fact, based on the previous observation done on the student's English textbook, the textbook that students didn't provide the relevant speaking learning material. It can be seen by student's handbook that government distributed for the 
school. The used in syllabus are irrelevant with the textbook, in the syllabus the students are expected to be able to express the meaning of transactional conversation and the meaning of the text. However, in the textbook is a most story and expression.

CTL is an approach of teaching and learning that helps the teacher to relate subject materials to the real world situations and motivates the student to make connection between knowledge and its application to their daily life. According to Johnson (2005:25):

"CTL is an educational process that aims to help student see meaning in the academic material they are studying by connecting academic subject with the context of their daily lives, that is with the context of their personal, social and cultural circumtances. To achieve this aim, system encompass the following eight components: making meaningful connection, doing significant work, self regulating learning, collaborating, critical and creative thinking, nurturing the individual, reaching high standarts, and using authentic assessment."

The Contextual Teaching and Learning concept believes that students will be able to learn better if they connect the content which they are currently studying to the life context in which the content can also be applied. This approach is the most appropriate to be used as the basic of designing the speaking materials because of its foundation, and constructivism. It will make the students understand and solve the problems, express and develop their ideas. 
Therefore, this study relates to develop English Speaking Materials based on Contextual Teaching and Learning for the second semester the eleventh grade students of SMA N 1 Kerajaan to help them improving their English skill. The concept of Contextual Teaching and Learning intended to create the meaningful English speaking learning process for the students. 


\section{REVIEW OF RELATED LITERATURE}

\section{The nature of speaking}

Speaking of language is a means of communication. Speaking is so complex, because it includes many aspects such as grammar, pronunciation, fluency and vocabularies. According to Nunan (2003: 48), speaking is a productive aural/oral skill. It involves the production of verbal utterance to grasp meaning. Bygate states as cited by Louma (2004:104), the special features of speaking results from two sets of condition under which people speak: processing and reciprocity. Processing means that speaking involving action which simultaneously happens. Reciprocity means what a speaker says according to what his or her listener's reaction.

\section{Contextual Teaching and Learning}

Berns and Erickson (2001: 2) define CTL as conception of teaching and learning that helps teachers relate subject matter or content to real world situations; and motivates students to make connections between knowledge and its applications to their lives.It focuses on the context of what we teach from the students ${ }^{\text {ee }}$ point of view.Muslich (2007:41) defines the foundation of Contextual Teaching and Learning is constructivism, which emphasizes that learning is not only memorizing, but also reconstructing or constructing new knowledge and new competence through facts or proportion which they experience in their life. This theory views learning as where the students 
construct their own understanding based on prior knowledge and experience and apply them in a new situation. Constructivism calls for active participation from the students. It means that they will be able to maximize their knowledge if they learn through the real life context materials.

\section{English Learning Materials}

Tomlinson (1998:2) states that materials refer to anything which is used by the teacher or learners to facilitate the learning of a language that is able to improve the students' knowledge and experience of the language. It means that materials are a set of product that teacher and student use in language teaching and learning.

Nunan (1991:208) says that materials are an important element within the curriculum and the most tangible and visible aspect of it. Richards (2001:251) defines instructional materials generally serve as the basis for much of the language input that learners receive and the language practice that occurs in the classroom. In conclusion materials are things used by the teacher or learners in teaching and learning process that give students opportunity to improve their skill and knowledge.

\section{Students Needs Analysis}

Need analysis is the first step to help the materials developer to create an appropriate materials based on the students need so that it helps the students comprehend the English materials. Every learner has their own need 
and interest to learn language. So, this reason gives us to recognize why the learners need to learn English. The stress of the term need is not only put on the existence of the need but also the awareness of the need. It's in line with Hutchinson and Waters (1987:53) who stress to not only focus to the existence of a need as such but also an awareness of the needs. This awareness then lead teachers to dig deeper not only what kind of material which will discover the learners true needs but so what potential can be exploited. 


\title{
RESEARCH METHODOLOGY
}

\author{
Methodology
}

The research will be conduct by using the Research and Development (R\&D). Educational R \& D is a development model in which the findings of research are used to design new products and procedures, which are systematically field-tested, evaluated, and refined until they meet specified criteria of effectiveness, quality, or similar standard Borg \& Gall (2003: 569). Borg and Gall (2003: 572) state that if you plant to do and R\&D project for a thesis or dissertation, it is best to undertake a small-scale project that involves a limited amount of original instructional design. R\& D has stages of educational research they are (1) Gathering Information and Data, (2) Analyzing the Data, (3) Designing New Materials (4) Validating New Materials by Experts, (5) Revising Materials, and (6) Final Product.

\section{Subjects of the Study}

The subjects of this research were the students in the second semester in the grade XI of Senior High School and the English teacher of Senior High School at SMA Negeri 1 Kerajaan

\section{Techniques and Instruments of Collecting the Data}

\section{a. Techniques}

Techniques The data of this research were gathered by using two techniques. The first technique was using questionnaire and the second technique was conducting interview.

b. Instruments 
The instruments which were used in this research were questionnaire and the question sheet. The questionnaires were designed based on theory of Hutchinson 8 and Waters about need analysis (1987: 55-63) and they were administered to the students in evaluation and need analysis stages in order to find out the data of students' necessities, lacks and wants. Meanwhile question sheet was used to ask some questions to the English teacher to get deeper infomation about students' necessities, lacks and wants in learning.

\section{Technique of Analyzing data}

The data of this study students' need analysis and existing materials. The data were analyzed to get the solution of students' problem and to find the appropriate speaking materials based on students' need. Later, this data were used to develop new speaking materials. 


\section{MATERIAL DEVELOPMENT}

The data in this research was collected by using some instruments, namely: questionnaire and interview. The questionnaire was administered to 20 respondents by the researcher to the students of Grade XI and the interview to the English teacher to gather a more detail data about the needs of Grade XI students so that, the appropriate English speaking materials based on contextual teaching and learning.

The questionnaire was administered to 20 students in grade XI of Senior High School at SMA Negeri 1 Kerajaan. They were given which consisted 20 questions. The questionnaire was developed based on the theory proposed by Hutchinson and Waters (1986:55), there are three categories of question which should be covered, namely: necessities, lacks, and wants. The three categories were presented in the questionnaire in which questions number 8 questioned about necessities, questions number 13 questioned about lacks, and questions number 6,7,and 14 questioned about wants. From the research, students need to learn English because English is important that English speaking material should make them able to understand.

After administering the needs analysis, the appropriate English speaking materials based on contextual teaching and learning for grade XI students were identified. The main point was the English speaking materials given should be related to their study. It was done not only to meet the students' needs in their learning process and also in their future job but also to make the students will be ease in speaking English so that the standard competences and based competences in 
syllabus could be achieved. In designed the English speaking materials, the researcher divided the English speaking materials related to the students of class XI high school into three units, The title for each unit were:

\begin{tabular}{|c|c|c|c|}
\hline No & $\begin{array}{c}\text { Existing English Speaking } \\
\text { Materials }\end{array}$ & No & $\begin{array}{c}\text { Developed English Speaking } \\
\text { Materials }\end{array}$ \\
\hline 1 & Tell me about & 1 & Come With Us \\
\hline 2 & Telling Stories & 2 & I'm So Happy \\
\hline 3 & Figuring Out Conclusion & 3 & Don't Be Sad My Friend \\
\hline
\end{tabular}

The next step was expert judgment process. The materials were evaluated by two Validators. The first validator came from an English Lecturer at State University of Medan and the second came from an English Teacher at SMA Negeri 1 Kerajaan. Based on the validated score, the developed materials got 4,7. It is categorized "Good". Based on the result, the developed English speaking materials are suitable and appropriate for the eleventh students.

After getting feedback from the experts, the reading materials were revised and written into the final draft. Finally, developing of the new materials based on the revision is done. 


\section{CONCLUSION AND SUGGESTIONS}

\section{Conclusion}

Developing Speaking Materials for Grade XI Students at SMA Negeri 1 Kerajaan follows Research and Development (R \& D) model by Gall, Borg and Gall's (2003) which was done through six steps, namely: gathering information and data, analyzing data, designing new materials, validating new materials by experts, revising materials and final product. The product of speaking materials for Grade XI Students at SMA Negeri 1 Kerajaan by two experts and the average score gotten is 4.7 (good). It means that the materials were valid and appropriate to use as learning materials for students of Grade XI at SMA N 1 Kerajaan Pakpak Bharat.

\section{Suggestions}

\section{Teacher}

This supplementary English speaking book can be used as the materials to teach the students in the teaching and learning process. The materials developed in the book are aimed to improve students' speaking skill. Teachers can use contextual based speaking book to teach some expressions in English used in daily life. Teachers are asked to read the teacher's guide book to know the procedures before using the book.

\section{Students}

The students of English Education Department were expected to become creative teacher in the teaching and learning process in the following year. They 
were expected to become a person to fulfill the students' needs in learning. To fulfill the students' needs the teacher should be more innovative and creative. Based on the needs analysis the speaking materials are successful in fulfilling the students' need.

\section{Other researchers}

expected to be able to develop an English learning material, especially speaking skill for other study programs which have the problems with the availability of appropriate English learning materials. They are also expected to find other characteristics of appropriate learning materials based on students' need, especially in designing English speaking materials. 


\section{REFERENCES}

Berns, R. \& Erickson, P. 2001. Contextual teaching and learning: Preparing students for the new economy. Washington: National Academy Press

Borg, W.R., Gall, M.D., and Gall, J.P. 2003. Educational Research: An introduction seventh edition. Boston: Ablongman.

Hutchinson, T \& Waters, A. (1986). English for Specific Purposes: A Learning Centered Approach. Cambridge: Cambridge University Press.

Hutchinson, T \& Waters, A. (1987). English for Specific Purposes: Alearning centred approach. Cambridge: Cambridge University Press.

Nunan, D. (2004). Task-Based Language Teaching. New York: Cambridge University Press.

Richards, J. C. (2001). Curriculum Development in Language Teaching. Cambridge: Cambridge University Press.

Tomlinson, B. (Ed). (1998). Material Development in Language Teaching. Cambridge: Cambridge University Press. 
